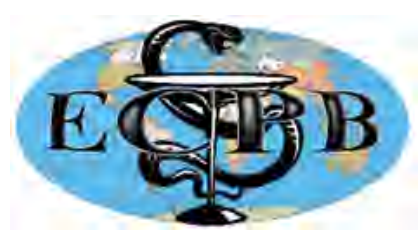

“ЕКСПЕРИМЕНТАЛЬНА ТА КЛІНІЧНА ФІЗІОЛОГІЯ І БІОХІМІЯ”

"EXPERIMENTAL AND CLINICAL PHYSIOLOGY AND BIOCHEMISTRY"

Науково-практичний журнал/Scientific-practical journal

Наукові статті / Research article

ECPB 2018, 3(83): 18-23. https://doi.org/

UDC 616-053.3-085.33.835.56.099-092.9

\title{
The Study of Acute Inhalation Effect of Nitroxoline on Experimental Animals
}

\author{
B.P. KUZMINOV, G.I. YASKIV, T.A. ALIYOKHINA \\ Danylo Halytskyi Lviv National Medical University, Lviv, Ukraine \\ E-mail: annajaskiv@ukr.net
}

Current tendencies of developing any production, including pharmaceutical, require complex studying of the influence of working conditions on health of employees. Manufacturing employees may be exposed to hazardous substances entering their respiratory system and reaching the skin and mucous membranes. The toxicity degree of chemical substances and nature of triggered disturbances depend on the chemical structure of a substance, its concentration in the air, and the duration of its exposure [1]. It proves the necessity of conducting hygienic estimation of working conditions for employees during manufacturing with the intention to improve these conditions and, therefore, preserve employees' health. Sanitary and hygienic assessment of hazardous working conditions in manufacturing is multifactorial and involves numerous examinations: the analysis of information concerning the safety of the medical raw material itself, the technological process of the production with the specification of intermediate compounds, data pertaining to the equipment, premises, hazardous manufacturing factors. Despite numerous efforts of hygienists and toxicologists, only insignificant part of required measures relating to hygienic estimation and regulation of chemical substances is being performed.

Our study of the hygienic regulation of medicine in the air of the manufacturing premises is dedicated to nitroxoline, one of the quinolones which is widely used for treatment of infectious diseases of genitourinary system [2]. This medication is effective against a wide range of gram-positive, gram-negative bacteria and fungi. Antibacterial and antifungal activity of the medication deals with the majority of genitourinary tract germs.

It is known that $\mathrm{DL}_{50}$ of nitroxoline for white female rats is 980 (852:1127) $\mathrm{mg} / \mathrm{kg}$, for white male rats it is equal to $835 \mathrm{mg} / \mathrm{kg}$, for white male mice it makes $660 \mathrm{mg} / \mathrm{kg}$ (hazard class III). An average effective time of death $\left(\mathrm{ET}_{50}\right)$ for white rats is equal to 28 hours. $\mathrm{CL}_{50}$ of nitroxoline for white female rats is $>2500 \mathrm{mg} / \mathrm{M}^{3}$ (hazard class II due to GOST 12.1.007-76), Limac is equal to $706,8 \mathrm{mg} / \mathrm{M}^{3}[3]$.

The study of toxicity of any substance is performed experimentally on the laboratory animals with complex examinations involving the estimation of the general state of the body, behavioral responses of animals, the total threshold potential, morphological changes in internal organs, in the system of blood homeostasis, etc. $[4,5]$.

The system of blood homeostasis performs numerous essential functions, provides and maintains the integrity of the body. It is extremely sensitive to various physiological, pathological effects, including toxic ones [6-8]. The blood changes - cellular characteristics, biochemical parameters are a subtle reflection of impacts on the body in the whole. The general and biochemical blood

(C) Kuzminov B.P., Yaskiv G.I., Aliokhina T.A., 2018 
analyses are mandatory examinations during professional medical examinations. Therefore, the importance and topicality of studying the acute effect of inhaled nitroxoline on blood homeostasis determined the aim of our research.

The tests were conducted with in the toxicological experiment on hygienic regulations elaborating admissible content of substances in the air of the working area at chemical and pharmaceutical enterprises. The article is a part of the thesis entitled "Toxicological and hygienic characteristics of nitroxoline with the assessment of specific effects in chemical and pharmaceutical manufacturing" (N of State Registration 0114U000110, code: 14.00.0001.09).

Purpose. To study the acute inhalation effect of nitroxoline on experimental animals.

Materials and methods. Nitroxoline is a uroantiseptic agent, CAS N 400848-4, poorly soluble in water, readily soluble in alkali and acids. The study of inhalation toxicity of the compound was performed on white, nonlinear rats with weight 150-250 g. The animals were kept at the vivarium of Danylo Halytskyi Lviv National Medical University according to the standard food ration. The research was conducted due to bioethics principles according to regulations of European Convention for Protection of Vertebrate Animals used for Experimental and other Scientific Purposes (Strasbourg, 1986), European Directive 2010/63/ EU, Law of Ukraine N 3447-IV "On the Protection of Animals from Cruelty".

The animals were divided into 4 groups by "blind ranging" method: the control group and 3 experimental groups, each containing 8 animals. Experimental groups were formed according to the concentration of single inhalation substance effect, namely: $23,4,7,8$ and $2,6 \mathrm{mg} / \mathrm{kg}$, with corresponding concentrations of the substance in the air: $706,8,235,6$ and $78,5 \mathrm{mg} / \mathrm{M}^{3}$. Concentrations of nitroxoline 706,8 and $78,5 \mathrm{mg} / \mathrm{m}^{3}$ were suprathreshold and subthreshold with reference to calculated threshold of the single inhalation effect that was equal to $235,6 \mathrm{mg} / \mathrm{m}^{3}$ [2]. The preparation was mixed with $0,9 \% \mathrm{NaCl}$ sterile solution. White rats were administered with $0,2 \mathrm{ml}$ of suspension intranasally by means of a dispenser with a soft plastic probe. Animals of the control group were administered with $0,2 \mathrm{ml}$ of $0,9 \% \mathrm{NaCl}$ solution.

Toxicity of a single inhalation effect of the preparation was assessed on the basis of indicators characterizing homeostasis, the functional state of the liver and kidneys, namely: haemoglobin level, erythrocytes, leucocytes and cell population count, alkaline phosphatase, aspartate (AST) and alanine transaminase (ALT), bilirubin, thymol test, total protein, urea, creatinine, indicators of thiopental sleep. The level of chemical-induced antigenic load was estimated by determining the circulating immune complexes (CIC) in the blood serum. Erythrocyte count and total leucocyte count were performed by the unified method in Goryaev's chamber. Pules of leucocyte cells were identified by the unified method of morphologic examination of formed blood elements with the differential leucocyte count. The obtained indicators were expressed in relative and absolute units as to 1 liter of blood on $10^{9} / \mathrm{l}$. The haemoglobin level and the above mentioned biochemical indicators were determined on the basis of common unified methods using reagents of research-and-production enterprise "Felicit-Diagnostics", Dnipro, Ukraine, CIC was determined spectrophotometrically, by precipitation method of high globular immune complex of blood with high-molecular weight polyethylene glycol (PEG), thiopental induced sleep. The above mentioned indicators were identified on the first and the second day after intranasal nitroxoline administration.

The statistical processing of data was performed by the variation statistics with calculating average units $(\mathrm{M})$, standard deviations of sampling distribution $(\mathrm{m})$, standard deviation $(\sigma)$, coefficient $(t)$ and the validity difference $(p)$ according to the Student's table.

Results and discussion. Studying of single inhalation effect of nitroxoline with the following concentrations of the medicinal substance in the air - 706,8, 235,6 and $78,5 \mathrm{mg} / \mathrm{m}^{3}$ - did not reveal reliable changes concerning indicators of 
peripheral blood in animals of the experimental groups and the control group on the first 24 hours of the experiment.

The considerable tendency to decreased erythrocyte count was noticed, on average by $21,4 \%$ on the second day after single inhalation effect of the substance in animals of experimental groups in comparison with initial indicators regardless the dosage of effect, namely: by $22,2 \%$ at the dosage that corresponds to the concentration of the compound in the air equals $706,8 \mathrm{mg} / \mathrm{m}^{3}$ $(t=1,58, p>0,05)$; by $19,9 \%$ at $235,6 \mathrm{mg} / \mathrm{m}^{3}(t=2,02, p>0,05) ;$ by $22,1 \%$ at 78,5 $\mathrm{mg} / \mathrm{m}^{3}(t=1,98, p>0,05)$. The decreased haemoglobin level in the experimental groups was inconsiderable and ranged from 2,0 to $9,8 \%$ relating to initial indicators (Table 1). The decreased indicators of "red" blood in case of studying the acute toxic action of the preparation, obviously, was related to erythrocytes haemolysis. It was proved by the tendency to increasing of the total bilirubin level in the blood serum of the animals, which was on the increase on the first day of the experiment at dosages of toxic effect with the corresponding concentrations: $706,8,235,6,78,5 \mathrm{mg} / \mathrm{m}^{3}$ by $7,7,11,5$ and $11,5 \%$ accordingly. On the second day, it was increasing by $17,8,21,2$ and $3,2 \%$ correspondingly (Table 2). Changes in leucocytes were not noticeable after the single intranasal administration of nitroxoline at set dosages.

The study of the inhalation toxicity in the single effect of nitroxoline set concentrations did not reveal any characteristic regularities on studied biochemical indicators. The exception was thiopental induced sleep in the group of animals which underwent effect of the inhalation with the concentration of $706,8 \mathrm{mg} / \mathrm{m}^{3}$. The duration of thiopental sleep increased by 1,9 times and made up 74,3 $\pm 2,7$ minutes, as to $38,3 \pm 2,6$ minutes in the control group $(t=9,47$, $p<0,001)$, that indicated changes of the functional state of the liver, namely, the failure of eliminating the function and, as a result, reaction of CNS on the triggering factor in the bloodstream. The duration of thiopental-induced sleep decreased by $35,8 \%(t=7,38, p<0,001)$ on the second 24 hours of the experiment but still remained considerably higher than indicators obtained in intact animals $(t=3,55, p<0,02)$. The received results proved the failure of physiological detoxifying capacities of the body to conjugate and eliminate nitroxoline from the body completely for 24 hours. Therefore, the concentration $706,8 \mathrm{mg} / \mathrm{m}^{3}$ is liminal as to the duration of thiopental induced sleep. This concentration is defined as $\operatorname{Lim}_{\mathrm{ac}}$ for white rats.

It should be mentioned that the acting agent revealed its action not as the irritator with features of valuable antigene, but as a toxic substance capable to influence the tissue metabolism in case of single inhalation. It is proved by the increased duration of thiopental sleep. The absence of reliable difference between indicators of circulating immune complexes, pules of eosinophile and basophile leucocytes in experimental and intact animals at the stage of single action of chemical compound indicated the absence of allergic susceptibility in the body, the absence of sensibilization and, correspondingly, specific antibodies capable to form circulating immune complexes with nitroxoline or with its metabolites.

Conclusions. 1. The acute threshold effect $\left(\operatorname{Lim}_{\mathrm{ac}}\right)$ of nitroxoline was 706,8 $\mathrm{mg} / \mathrm{m}^{3}$ due to the indicator of thiopental induced sleep duration for white rats in case of inhalation. 2. Single inhalation effect of nitroxoline in the following concentrations of the compound in the air $-706,8,235,6$ and $78,5 \mathrm{mg} / \mathrm{m}^{3}-\mathrm{re}$ vealed slightly noticeable haemolytic effect. It was proved by the tendency to the decreased erythrocyte count by $22,9 \%(t=1,50, p>0,05)$, by $19,9 \%(t=1,04$, $p>0,05)$, by $22,1 \%(t=1,0, p>0,05)$ during 24 hours after the inhalation effect of the compound in comparison with initial indicators and did not cause the reliable re-distribution of the cellular structure of peripheral blood, biochemical indicators and circulating immune complexes. 3. The chemical structure of nitroxoline molecule did not reveal properties of valuable antigene capable to trigger toxic and allergic processes in case of the single inhalation effect. 
$\frac{0}{\frac{1}{\pi}}$

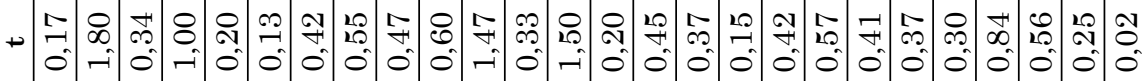
: घ

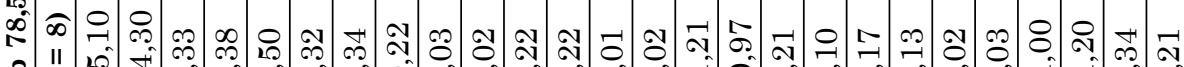

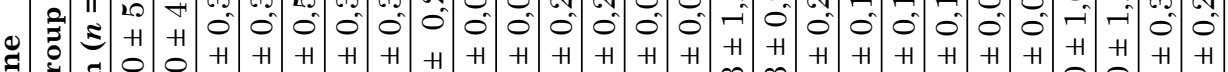
:

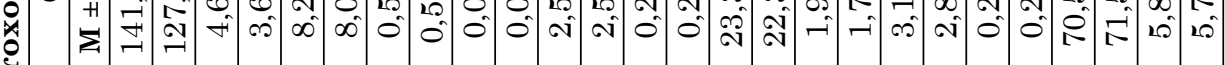

:

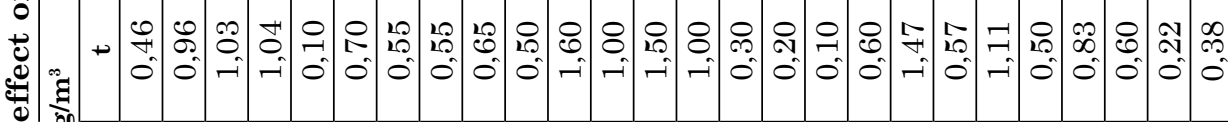

ฐิ)

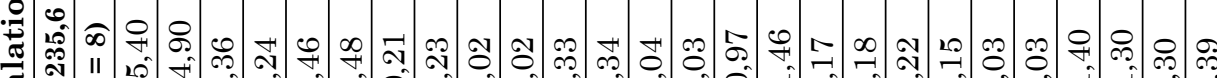
寻 Z

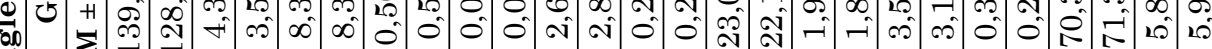

a

响 ह 0 0 ઔ.

茪

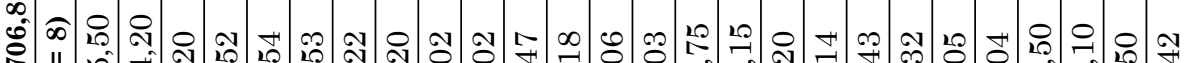

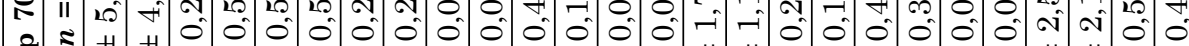
$\Xi 2+\mathrm{H}+\mathrm{H}+\mathrm{H}+\mathrm{H}$ H H H H H H H H H H H H H H H H H H

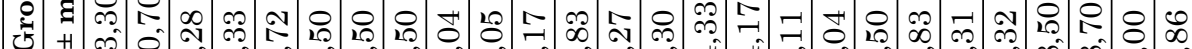
$\Xi$ I $\Rightarrow$ जी

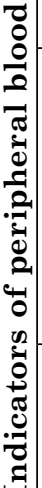

5

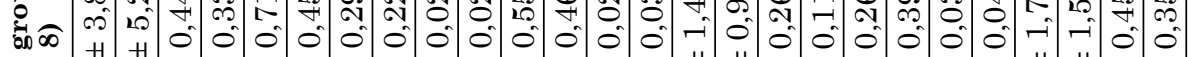
2 O II 0 O

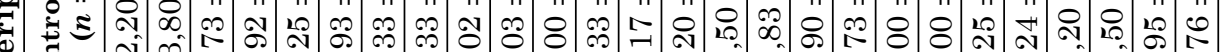
ڤ.

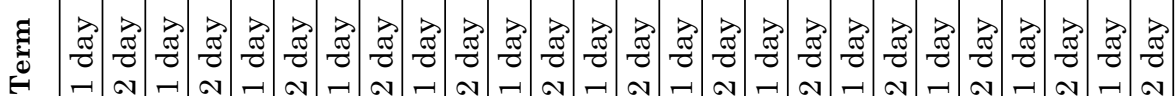

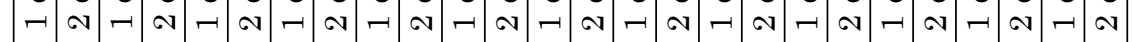

\begin{tabular}{|c|c|c|c|c|c|c|c|c|c|c|c|c|c|}
\hline & 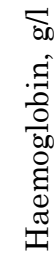 & 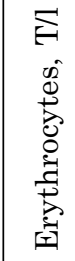 & 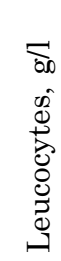 & 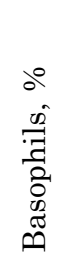 & 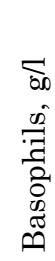 & 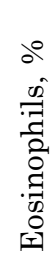 & 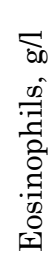 & $\begin{array}{l}\text { do } \\
\text { की } \\
\overline{\mid} \\
0 \\
0 \\
0 \\
0 \\
0 \\
z\end{array}$ & 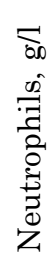 & $\begin{array}{l}\text { of } \\
\text { Dी } \\
0 \\
0 \\
0 \\
0 \\
\sum\end{array}$ & 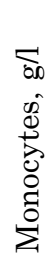 & 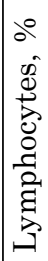 & 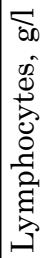 \\
\hline
\end{tabular}




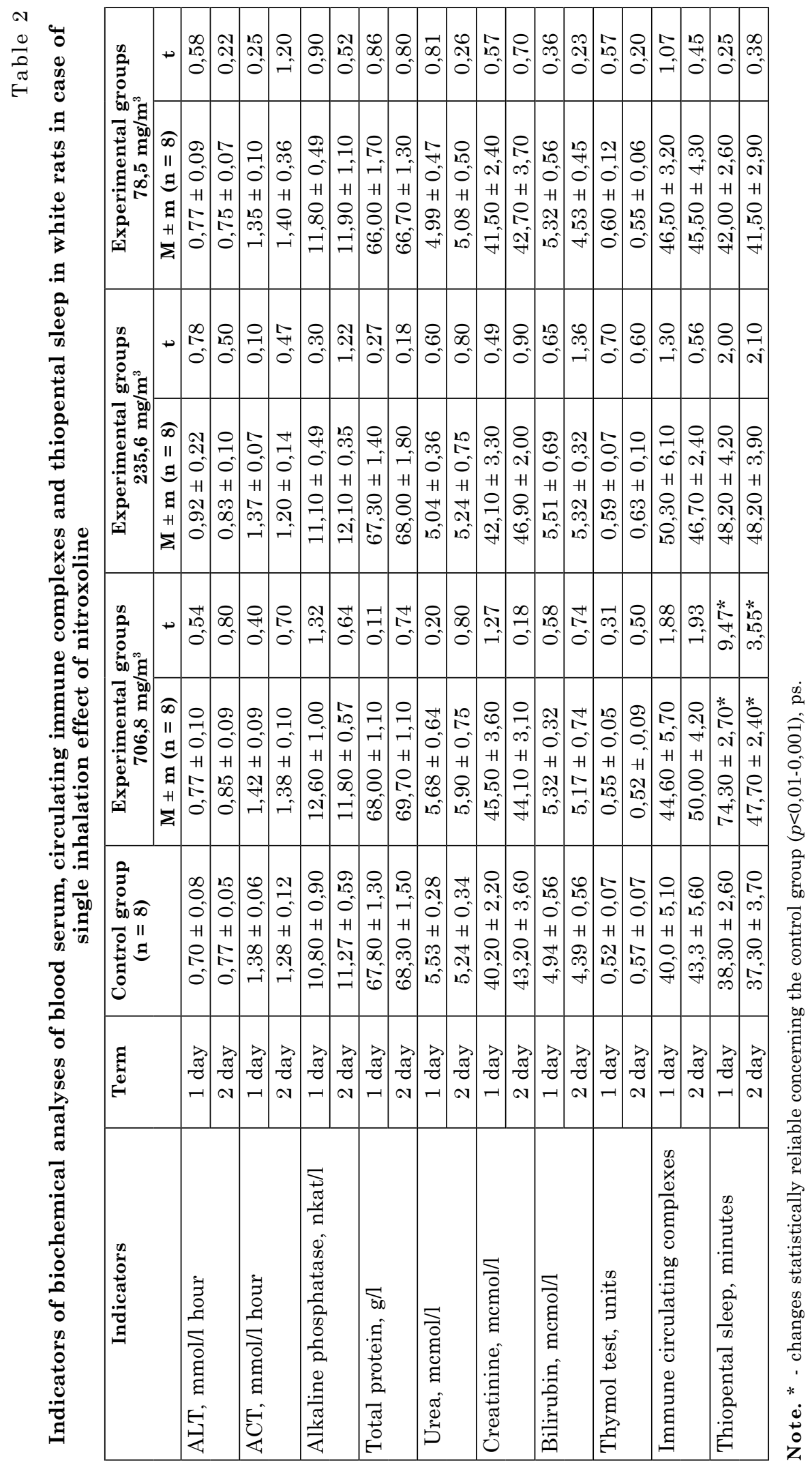

Рекомендовано до друку колісією з біоетики 


\title{
REFERENCES
}

1. Петренко О. Вплив шкідливих хімічних речовин на організм працівника виробництва. Вимірювальна техніка та метрологія. 2009;70:210-2 (Petrenko O. Vplyv shkidlyvykh khimichnykh rechovyn na orhanizm pratsivnyka vyrobnytstva. Vymiriuvalna tekhnika ta metrolohiia. 2009;70:210-2). 2. Яськів ГI. Первинна токсикологічна ощінка нітроксоліну на лабораторних тваринах. Медичні перспективи. 2017;22(1):111-4 (Yaskiv HI. Pervynna toksykolohichna otsinka nitroksolinu na laboratornykh tvarynakh. Medychni perspektyvy. 2017;22(1):111-4). 3. Кузьлінов БП, Зазуляк ТС, Яськів ГІ, Туркіна ВА. Обгрунтування орієнтовно безпечного рівня впливу нітроксоліну у повітрі робочої зони виробничих приміщень. Сучасні проблеми токсикології, харчової та хімічної безпеки. 2016;3(75):39-42 (Kuzminov BP, Zazuliak TS, Yaskiv GI, Turkina VA. Obhruntuvannia oriientovno bezpechnoho rivnia vplyvu nitroksolinu u povitri robochoi zony vyrobnychykh prymishchen. Suchasni problemy toksykolohii, kharchovoi ta khimichnoi bezpeky. 2016;3(75):39-42). 4. Коцюмбас IЯ, Малик ОГ, Патерга IП, Тішин ОЛ, Косенко ЮМ. та ін. Доклінічні дослідження ветеринарних лікарських засобів. За ред. ІЯ Коцюмбаса. Львів: Тріада плюс; 2006. 360 (Kocyumbas IYa, redactor. Doklinichni doslidzhennia veterynarnykh likarskykh zasobiv. L'viv: Triada plyus; 2006. 360). 5. Трахтенберг ИМ, Тыєчинин ВА, Сова РЕ, Коршун МН, Лубянова ИП и др. Основные показатели физиологической нормы у человека: руководство для токсикологов. Под ред. ИМ. Трахтенберга. Киев: Авиценна; 2001. 372 (Trahtenberg IM, Tyichin VA, Sova RE, Korshun MN, Lubyanova IP; Trahtenberg IM, redactor. Osnovnyie pokazateli fiziologicheskoy normyi u cheloveka: rukovodstvo dlya toksikologov. Kyiv: Avitsenna; 2001. 372). 6. Кузник БИ. Клеточные и молекулярные механизмы регуляции системы гемостаза в норме и патологии. Чита: Экспресс-издательство; 2010. 832 (Kuznik BI. Kletochnyie i molekulyarnyie mechanizmyi regulyatsii sistemyi gemostaza v norme i patologii. Chita: Ekspress-izdatelstvo; 2010. 832). 7. Лазаренко IA, Мельникова НM. Порівняння біохімічних показників крові щурів за отруення їх свинцем в макродисперсній та наноформі. Український біохімічний журнал. 2012;1(84):85-9 (Lazarenko IA, Melnykova NM. Porivniannia biokhimichnykh pokaznykiv krovi shchuriv za otruiennia yikh suyntsem v makrodyspersnii ta nanoformi. Ukrainskyi biokhimichnyi zhurnal; 2012;1(84):85-9). 8. Владимирская $E Б$. Клиническое значение анализа крови: лекция. Режим доступа: www. intermedika.ru/article/laboratornaja-diagnostika-klinicheskoe-znachenie-analiza (Vladymyrskaia EB. Clinical significance of blood test. Lektsyia. Internet: Rezhym dostupu: http://unimedao. ru/articles/6826/9671/item/28).

Стаття надійшла до редколегії 03.09.2018

\section{RESEARCH ARTICLES}

\section{The Study of Acute Inhalation Effect of Nitroxoline on Experimental Animals}

\author{
B.P. KUZMINOV, G.I. YASKIV, T.A. ALIYOKHINA \\ Danylo Halytskyi Lviv National Medical University, Lviv, Ukraine
}

\section{E-mail:annajaskiv@ukr.net}

Introduction. The effect of acute nitroxoline inhalation on experimental animals was studied. The test was performed on 4 groups of white rats, containing 8 animals, by intranasal administration of $0.2 \mathrm{ml}$ of nitroxoline solution. Animals of the control group were injected with $0.2 \mathrm{ml}$ of $0.9 \% \mathrm{NaCl}$ solution.

Materials and methods. The experimental groups were formed according to the concentration of the single inhalation effect of a substance that corresponded to the suprathreshold, threshold and subthreshold concentrations of the compound in the working zone air concerning the calculated threshold of a single inhalation action.

Results. It was determined that acute nitroxoline inhalation effect in the following concentrations - 706.8, 235.6 and $78.5 \mathrm{mg} / \mathrm{m}^{3}$ - did not cause changes in the blood hemogram, biochemical parameters and circulating immune complexes on the first day of the experiment. The noticeable tendency towards the decreased erythrocyte count and the increased bilirubin level was observed on the second day after a single inhalation effect of the compound in animals of the experimental groups, although the indicators were not statistically significant $(p>0.05)$.

The concentration of nitroxoline $706.8 \mathrm{mg} / \mathrm{m}^{3}$ prolonged the duration of thiopental sleep by 1.9 times on the first day $(p<0.001)$ and by 1.3 times on the second day $(p<0.01)$ of the experiment. The obtained results proved the failure of the physiological detoxifying capacities of the body to conjugate and remove nitroxoline from the body completely during 24 hours.

Conclusions. The threshold of nitroxoline acute action (Lim ac) due to the duration of thiopental sleep for white rats in case of inhalation was $706.8 \mathrm{mg} / \mathrm{m}^{3}$. The chemical structure of the nitroxoline molecule did not reveal the properties of a valuable antigen capable of triggering toxic and allergic reactions in case of the single inhalation effect on the body.

Key words: nitroxoline, acute inhalation effect, toxicity assessment, blood. 